\title{
Editorial: Ways of Seeing Women's Leadership in Education-Stories, Images, Metaphors, Methods and Theories
}

\author{
Kay Fuller ${ }^{1 *}$, Pontso Moorosi ${ }^{2}$, Victoria Showunmi ${ }^{3}$ and Saeeda Shah ${ }^{4}$ \\ ${ }^{1}$ School of Education, University of Nottingham, Nottingham, United Kingdom, ${ }^{2}$ Centre for Education Studies, University of \\ Warwick, Coventry, United Kingdom, ${ }^{3}$ UCL Institute of Education, University College London, London, United Kingdom, ${ }^{4}$ School \\ of Education, University of Leicester, Leicester, United Kingdom
}

Keywords: women, gender, feminism, educational leadership, images and metaphors, methods, theories

Editorial on the Research Topic

Ways of Seeing Women's Leadership in Education-Stories, Images, Metaphors, Methods and Theories

\section{OPEN ACCESS}

Edited and reviewed by: Margaret Grogan,

Chapman University, United States

${ }^{*}$ Correspondence: Kay Fuller

Kay.Fuller@nottingham.ac.uk

Specialty section:

This article was submitted to Leadership in Education, a section of the journal

Frontiers in Education.

Received: 22 September 2021 Accepted: 28 September 2021 Published: 05 November 2021

Citation:

Fuller $K$, Moorosi $P$, Showunmi $V$ and Shah S (2021) Editorial: Ways of Seeing Women's Leadership in

Education-Stories, Images,

Metaphors, Methods and Theories.

Front. Educ. 6:781049.

doi: $10.3389 /$ feduc.2021.781049

\section{INTRODUCTION}

Gender and educational leadership remains a focus for scholarly interest precisely because gender inequalities remain. That is the case 30 years on from the publication of seminal works that established gender and women in educational leadership as a focus for research (Shakeshaft 1987; Blackmore 1989; Dillard 1995). Scholars continue to document women's under-representation in leadership (Alston, 2005). This Research Topic focuses on accounts of doing leadership (e.g. Cook), as well as showing how their inclusion transforms leadership theory e.g. by incorporating gender, feminist, intersectionality and Afrocentric theories (e.g. Gullo and Sperandio, Tripses and Lazaridou, Malachias et al., Williams). Feminist epistemology ensures women's experiences and ways of seeing are central to the research purpose and process; that women as leaders are not solely the object of the researcher's gaze. In particular, feminist standpoint theory recognises there is epistemic privilege so that situated knowledge, what is known and the ways it can be known, is shaped by the positionality of knowledge producers. A reflexive approach prompts feminist researchers to reflect deeply on context, as well as their positionality, in relation to the focus of research. The theme of this Research Topic- "Ways of seeing women's leadership in education: stories, images, metaphors, methods and theories"-reflects collective experiences from diverse perspectives. Earlier versions of these eighteen papers were first presented at the seventh Women Leading Education across Continents conference at the University of Nottingham, UK in the summer of 2019.

\section{STORIES}

Papers draw on individual narratives, as autoethnographies (e.g. Fuller, Kappert, Williams) and narrative inquiries (e.g. Cook, Reilly, Showunmi). Annette Kappert complements her presentation of critical cultural autoethnographical stories of leadership with fictionalised stories and poetry using a historical lens to illustrate the value of conducting research into a female Black and Minority Ethnic educator's personal and 
professional experiences; she "gives voice to previously silenced and marginalized experiences" (Boylorn and Orbe 2014 p. 15).

Victoria Showunmi offers a view on narrative inquiries based upon leadership through a lens of gender, race and class. The paper takes the reader through a journey of difference as it navigates with the voices of women leaders across three countries. Elizabeth Reilly's work in the context of Rwanda explores and gives voice to Rwandan women leaders. The research draws on African feminist theories that explicitly challenge Western theories of gender and focus on "mov[ing] gender research towards post-colonial and indigenous approaches and the construction of knowledge derived from the experiences of girls/women in their specific locations and histories" that emphasize agency, resilience, and persistence (Chilisa and Ntseane, 2010 p. 620).

Pontso Moorosi uses narratives to portray the construction of leadership identity by three women leaders in African schools. These women's stories demonstrate how a leadership selfperception instils a sense of agency that facilitates leaderful actions to strengthen leadership identity. Women's stories of leadership identity development are gendered and shaped by values instilled from childhood that shape their leadership dispositions. The paper highlights the intricate nature of selfperception, gender and leadership identity, arguing that these aspects cannot be left to chance if we are serious about leadership development and increasing the pool of women in leadership.

Sheralyn Cook explores the stories of two women's professional and personal struggles turning around the New Zealand schools they led during turbulent times.

\section{IMAGES AND METAPHORS}

Sharon Curtis's paper positions the experiences of Black women leaders as a metaphorical visualisation of a single thread. A thread that manoeuvers and meanders apparently aimlessly, not through choice, but enforced by navigating a way through institutions and systems, fuelled with micro aggressions, convoluted racial barriers and obstacles placed in their paths and journeys as Black women reach for and sustain leadership positions.

Innovative work, exploring the metaphors and images used to describe leadership in a range of cultural contexts, reveals how differently we conceptualise women's leadership across continents (e.g. Randell and Yerbury, Burkinshaw and White). Shirley Randell and Hilary Yerbury attempt to break the mould, through the use of metaphors as a way to understand women's leadership across two different continents. The paper draws on the notion that leadership is generally thought of as "a good thing", as something important carried out by people with desirable attributes, such as courage and insight, or with attractive personalities and communication skills. However, using metaphors that highlight the obstacles women face, for example, the glass ceiling, glass cliff, sticky floors and the labyrinth is ubiquitous in educational leadership. Instead, they demonstrate women's alternative use of metaphors from the natural world.

Paula Burkinshaw and Kate White explore the use of images and metaphors to describe doing leadership across two generations of women leaders in higher education in two different country contexts. This innovative approach draws from experiences of an older generation of women in top leadership in the UK and a younger generation in middle leadership in Australia. They established that the older generation of women leaders conforms to metaphors and images of masculinist leadership thereby maintaining the status quo, while the younger generation use more positive images of leadership to disrupt the status quo. They portray an alternative model of leadership constructed on re-negotiated terms that bear more prospects for equality.

\section{METHODS}

Rosangela Malachias et al. innovative use of film narratives reveals women's activist leadership as community educators and film-makers in the Baixada Fluminense region near Rio de Janeiro, Brazil. These stories: of a Black deaf woman teaching the history and culture of black deaf people; and "a young black woman, graffiti artist, filmmaker, actress, and pedagogical specialist with a master's degree in Education" demonstrate that educational leadership can be found in communities even when there is limited recognition of it in the academy.

Pen Mendonça demonstrates the power of graphic illustration in articulating and exploring women's leadership through valuesbased cartooning. She provides a powerful personal account of her work with women leaders working in higher education and with grassroots movements. Her use of visual methods is innovative in the field of women, gender and feminism in educational leadership. Both papers expand the field to consider the leadership of women's leadership activism in education.

Kay Fuller has developed an intersectional life grid at 7 year intervals in her critical autoethnography to reveal reflexivities of complacency, reflexivities that discomfort and reflexivities that transform in a scholarly and professional career in educational leadership.

Historical research by Jenny Tripses and Angeliki Lazaridou make certain that women are written into the field to ensure we know "where we have come from, and where we are going". In particular, they focus on the lives of two women with long-lasting and powerful legacies-one Greek, the other American-Aikaterini Laskaridou and Lydia Moss Bradley lived and worked in the 19th century.

Qualitative methods such as narrative inquiry (e.g. Cook, Moorosi) and life story (e.g. Cunneen) bring out the depth of emotions, feelings and images attached to the gendered stories of women's lives. Analyses of quantitative data enable analysis of larger datasets about women's ways of doing leadership (e.g. Calderone et al., Reed and Reedman).

Diane Reed and Ashley Reedman use quantitative methods to compare leader resilience by gender and age. Based on an ongoing study that involves women and men, this innovative work shows that resilience increases with age for both genders. This work centres important life aspects such as well-being, resilient 
aging and quality of life. Increasingly, wellbeing is receiving attention as an important element to work-life balance for women in leadership and Reed and Reedman's work is on point.

Gina Gullo and Jill Sperandio's paper investigates the career paths and perspectives of current and aspirant superintendents in Pennsylvania. The research uses a mixed method approach which includes both quantitative and qualitative tools. Initial findings suggest, that there are similarities and differences in career planning preferences by men and women aspirant superintendents indicates an understanding by women of the insider pathway potential to overcome bias regarding women in leadership roles. As this career path is frequently not an option, women must choose not to aspire or to prepare themselves for possible gender bias in hiring when applying as outsiders.

\section{THEORIES}

To illustrate how structural inequalities operate at multiple levels, scholars show how the use of gender (e.g. Gullo and Sperandio), feminist (e.g. Calderone et al., Tripses and Lazaridou), critical race (e.g. Curtis), intersectionality (e.g. Fuller, Showunmi) and other social theories (e.g. Kappert) enables us to think about and articulate our ways of seeing women's leadership in formal and informal educational settings for learners of all ages.

Laura Burton's et al. paper examines how ten Black female school leaders coped with gendered racism and the costs associated with doing so. Their use of adaptive and maladaptive strategies, more or less affirming, highlighted the ways both types of strategies were effective and enabled participants to persist and succeed in their leadership roles.

Calderone et al. draw on feminist life course theory to understand how women's perspectives on the accessibility of the (United States) superintendency have shifted in recent times to become a largely contingent decision-a strategic, individual-level assessment focusing on the favourability of district work conditions to their success as leaders.

Patricia Williams draws on African-centred pedagogy, African womanism, and transformational leadership to explore her

\section{REFERENCES}

Alston, J. A. (2005). Tempered Radicals and Servant Leaders: Black Females Persevering in the Superintendency. Educ. Adm. Q. 41 (4), 675-688.

Blackmore, J. (1989) "Educational Leadership: A Feminist Critique and Reconstruction," in Critical Perspectives on Educational Leadership. Editors J. Smyth (London: Falmer).

Boylorn, R. M., and Orbe, M. P. (Editors) (2014) Critical Autoethnography: Intersecting Cultural Identities in Everyday Life. Walnut Creek, CA: Left Coast Press.

Chilisa, B., and Ntseane, G. (2010) Resisting Dominant Discourses: Implications of Indigenous, African Feminist Theory and Methods for Gender and Education Research, Gender and Education. 22 (6), 617-632.

Dillard, C. (1995). Leading with her Life: An African American Feminist (re) interpretation of Leadership for an Urban High School Principal. Educ. Adm. Q. 31 (4), 539-563.

Fuller, K., Moorosi, P., Shah, S., and Showunmi, V. (2020). Coming Full Circle: The Gender and Leadership Research Interest Group. Manag. Educ. 34 (3), 115-116.

Shakeshaft, C. (1987) Women in Educational Administration. Newbury Park, CA: Sage. leadership practice in a Charter School in an autoethnographical account that locates her experience in a neoliberal context.

\section{COLLECTIVE EXPERIENCE}

Importantly, these papers document the collective experiences of women leading education across continents. Of course, there are accounts of similarities and differences among the women whose leadership stories are told. Collectively, the papers present women leaders in their heterogeneity. There are accounts of challenges faced and overcome; of resistance enacted and agency exercised against the backdrop of institutional, systemic and societal misogyny and racism. Importantly there are accounts of abundance in their cultural and leadership capital.

In this collection of papers, intercontinental perspectives are presented from South America (Malachias et al.), North America (Burton et al., Calderone et al., Gullo and Sperandio, Reed and Reedman, Williams), Europe (Cunneen, Curtis, Fuller, Mendonça), Africa (Moorosi, Reilly), Asia (see comparative scholarship) and Australasia (Cook). Cross-continental perspectives are found in comparative scholarship (Burkinshaw and White, Randell and Yerbury, Showunmi, Tripses and Lazaridou) and the transcontinental life histories of educational leaders (Kappert).

However, the underrepresentation of papers in this collection from South American, African, Middle Eastern and Asian countries, when scholars from those continents presented their research at the conference in 2019 reveals the persistence of coloniality in knowledge production and dissemination in the field of women, gender and feminism in educational leadership. It persists despite best efforts to decolonise the conference (Fuller et al., 2020).

\section{AUTHOR CONTRIBUTIONS}

All authors listed have made a substantial, direct, and intellectual contribution to the work and approved it for publication.

Conflict of Interest: The authors declare that the research was conducted in the absence of any commercial or financial relationships that could be construed as a potential conflict of interest.

The handling editor declared a shared committee (Women Leading Education Across Continents) with the authors at time of review.

Publisher's Note: All claims expressed in this article are solely those of the authors and do not necessarily represent those of their affiliated organizations, or those of the publisher, the editors and the reviewers. Any product that may be evaluated in this article, or claim that may be made by its manufacturer, is not guaranteed or endorsed by the publisher.

Copyright (c) 2021 Fuller, Moorosi, Showunmi and Shah. This is an open-access article distributed under the terms of the Creative Commons Attribution License (CC BY). The use, distribution or reproduction in other forums is permitted, provided the original author(s) and the copyright owner(s) are credited and that the original publication in this journal is cited, in accordance with accepted academic practice. No use, distribution or reproduction is permitted which does not comply with these terms. 